\title{
Study on the relationship between some trace mineral elements and antioxidant enzymes among under-five children with protein-energy malnutrition
}

\author{
Stella U Njoku ${ }^{\text {* }}$, Kola M Anigo ${ }^{1}$, Shehu A Akuyam², Gboye O Ogunrinde ${ }^{3}$ and Stanley IR Okoduwa ${ }^{1,4,5}$ \\ ${ }^{1}$ Department of Biochemistry, Ahmadu Bello University, Zaria, Nigeria \\ ${ }^{2}$ Department of Chemical Pathology, Ahmadu Bello University Teaching Hospital, Zaria, Nigeria \\ ${ }^{3}$ Department of Pediatrics, Ahmadu Bello University Teaching Hospital, Zaria, Nigeria \\ ${ }^{4}$ Directorate of Research and Development, Nigerian Institute of Leather and Science Technology, Zaria \\ ${ }^{5}$ Infohealth Awareness Unit, SIRONigeria Global Limited, Abuja, Nigeria
}

\begin{abstract}
Background: The devastating effects of protein energy malnutrition (PEM) among children below age 5-years have been linked with increased free radical toxicity. The ability of antioxidant enzymes to scavenge these free radicals depends on some trace mineral elements.

Method: This study therefore investigated the relationship between some trace elements and endogenous antioxidant enzymes in 98 under-five children with proteinenergy malnutrition (PEM) and 98 age- and sex-matched apparently healthy children (control). Venous blood ( $2 \mathrm{ml}$ ) was collected from all subjects for biochemical analysis using standard methods.

Results: Results obtained show that mean serum total protein $(55.76 \pm 3.95)$ and albumin $(26.43 \pm 2.78)$ levels and superoxide dismutase (SOD) (1.87 \pm 0.32$)$ and glutathione peroxidase $(\mathrm{GPx})(42.38 \pm 5.03)$ activities in malnourished children were significantly lower $(\mathrm{p}<0.05)$ than in the control. Mean serum zinc $(\mathrm{Zn})$ concentrations $(8.37 \pm 4.25)$ in malnourished children were significantly higher $(\mathrm{p}<0.05)$ than in the control $(5.14 \pm 2.39)$, but mean serum copper $(\mathrm{Cu})$ concentrations in malnourished $(2.40 \pm 1.12)$ children were lower than in the control $(2.82 \pm 1.18)$. There were correlations between these serum levels of trace elements $(\mathrm{Zn}$ and $\mathrm{Cu}$ ) and antioxidant enzymes (SOD and GPx) in children with PEM and control. Marasmus (SOD-Zn: 0.03, SOD-Cu: 0.16, GPx-Zn: -0.14, GPx-Cu: 0.05), kwashiorkor (SOD-Zn: -0.39, SOD-Cu: -0.39, GPx-Zn: -0.54, GPx-Cu: -0.31), marasmic-kwashiorkor (SOD-Zn: -0.31, SOD-Cu: -0.51, GPx-Zn: -0.41, GPxCu: -0.48) and control (SOD-Zn: 0.12, SOD-Cu: 0.07, GPx-Zn: -0.07, GPx-Cu: -0.08).
\end{abstract}

Conclusion: This study reveals that children with PEM are predisposed to high oxidative stress due to increase in free radical production and decrease in antioxidant defense system. Therefore, routine laboratory investigation of antioxidants should be conducted for effective management of PEM.

\section{Introduction}

Severe malnutrition is one of the most important underlying causes of nearly half of all deaths in children under 5 years of life [1]. The major causes for this are poverty, world conflicts, lack of education, natural disasters and poor access to health care resources [2-4]. It is responsible for at least half of the 7.6 million deaths among children each year in developing countries [5]. Protein-energy malnutrition (PEM) is one of the most prevalent and devastating forms of malnutrition in developing world [6,7]. It is defined as the cellular imbalance between the supply of nutrients and energy and the body's demand for them to ensure growth, maintenance, and specific functions [8,9]. PEM results from inadequate intake and absorption which may be due to diseases, insufficient household food security, inadequate maternal and child care, poor sanitation and ignorance [10,11].

Marasmus, kwashiorkor and marasmic-kwashiorkor are clinical forms of severe PEM $[2,12,13]$. Marasmus is characterized by muscle wasting, anaemia, severe weight loss, growth impairment as well as dry and thin hair [14]. Kwashiorkor is characterized by apathy, increased susceptibility to infection, hypoalbuminemia, oedema, weight loss, growth impairment as well as dry and brittle hair and skin lesions [14]. The clinical onset of kwashiorkor usually takes place in a shorter period of time as compared to marasmus. Marasmickwashiorkor occurs when there are symptoms of both marasmus and kwashiorkor $[2,15]$.

It has been reported previously that, of all children under the age of five who suffer from PEM in developing countries, about $38 \%$ are stunted (low height-for-age), $31 \%$ are underweight (low weight-forage) and $9 \%$ are wasted (low weight-for-height) [16,17]. In Nigeria, about $52.6 \%$ of under-five children are stunted, $35.1 \%$ are underweight and $19.9 \%$ are wasted [18]. In Kaduna state, $6.8 \%$ prevalence of PEM was reported in Zaria [19]. Malnutrition leads to depletion of hepatic antioxidant stores and enhances hepatic release of free radicals [20]. The harmful effects of these free radicals have been documented in

*Correspondence to: Stella U. Njoku, Department of Biochemistry, Ahmadu Bello University, Zaria, Nigeria, E-mail: stella60090911@gmail.com

Key words: Protein energy malnutrition, Trace mineral element, Antioxidant enzymes, Under five children

Received: March 02, 2018; Accepted: April 03, 2018; Published: April 06, 2018 

malnutrition

children with PEM which is responsible for cell damage leading to oedema, fatty liver and skin lesions [21].

As described in detail previously [22,23], a state of equilibrium occurs between production of free radicals and antioxidant defense system in every organism under standard physiological conditions, which enable them to neutralize and guard against free radical toxicity. The concentrations of free radicals are kept at non-detrimental levels by the existence of antioxidant defense system in the cells. Nevertheless, the rate of damage caused by free radicals toxicity increases in PEM, which results in decreased efficiency of antioxidative and its repair mechanisms [24]. Excessive production of free radical arising from imbalance in the oxidant/antioxidant equilibrium creates a condition known as oxidative stress [23]. The detrimental consequence of these free radicals can be prevented by antioxidants. However, the efficacy of antioxidant enzymes in scavenging free radicals depends on their antioxidant cofactors [25]. These cofactors are trace mineral elements such as Zinc, Copper, Molybdenum and Selenium, which form the structural bases for the efficacy of the antioxidant enzyme defense system [25]. Antioxidant enzymes like superoxide dismutase (SOD) and glutathione peroxidase (GPx) are directly involved in the detoxification of free radicals through catalytic action [26]. These antioxidant enzymes are synthesized by the body but the trace elements (Selenium, Zinc and Copper) needed as cofactors must be supplied by the diet. Reduced levels of these antioxidant enzymes (SOD and GPx) and their cofactors have been found in children with severe PEM which results in build-up of free radicals [27,28].

Protein-energy malnutrition (PEM) has a great adverse effect on health resulting in poor growth, impaired immunologic factors, irritability, apathy and delayed cognitive development [29]. Oedema, skin lesion, fatty liver found in severe protein-energy malnourished children has been reported to be as a result of the harmful effects of free radicals [21] and reduced level of antioxidant defense system. Therefore, there is need to carry out a comprehensive study that will provide information for the better management of malnourished children. Although evidence on the relationship between trace elements and PEM is known [29], there is no sufficient evidence or data on the relationship between trace elements and antioxidant enzymes among under-five children with PEM in Nigeria. Therefore, the results of this study could broaden the understanding of the relationship between trace elements and antioxidant enzymes in protein-energy malnourished children in Nigeria with a view to formulating nutrition intervention programmes and policies targeted at reducing the prevalence of this disease and its detrimental effect among under-five children.

\section{Subjects and methods}

\section{Subjects}

The study was conducted in the Out-Patient Clinics of the Department of Paediatrics, Ahmadu Bello University Teaching Hospital (ABUTH), Shika-Zaria, during the period of May 2013 to May 2014. A total of 98 under-five children with PEM were recruited for this study and they were age- and sex- matched with 98 apparently healthy wellnourished under-five children as controls based on clinical findings and anthropometric parameters. The patients were divided into five different socio-economic classes as described by Olusanya, et al [30]. Arrangements were made with the clinicians whereby children who satisfied the study inclusion criteria were selected. Informed consent for inclusion into this study was sought from the parents/guardians of the selected children using standard protocol. Relevant information such as the demographic and socio-economic characteristics was obtained from the parents/guardians of the selected child through oral interview. Ethical approval (protocol number: ABUTH/HREC/ C32/2012) was obtained from the Ethical Committee of ABUTH, Shika-Zaria, in accordance with Helsinki declaration.

\section{Blood sample collection}

Two milliliters of blood sample were collected from peripheral vein by venipuncture using a sterilized syringe from each subject. This procedure was carried out by the paediatricians. This was performed using a syringe and needle after sterilizing the site with methylated spirit. The antecubital fossa was cleaned with methylated spirit and allowed to dry. A tourniquet was applied a few centimeters above the antecubital fossa to distend the veins, after which blood sample was collected using a sterilized $5 \mathrm{ml}$ syringe and $23 \mathrm{G}$ needle. The blood was placed in sample bottles and allowed to stand between 30-60 minutes for spontaneous blood clotting. The serum was separated from the blood cells by centrifugation at $4000 \mathrm{rpm}$ for 5 minutes at room temperature and decanted using a Pasteur pipette and used for the assays.

\section{Biochemical analysis}

Serum total protein levels were determined using Biuret method as described by Reinhold [31]. Serum albumin levels were determined by the bromocresol green (BCG) method as described by Hill [32]. Serum zinc and copper levels were determined using atomic absorption spectrophotometer (Model No. AA240FS), Varian, Sweden. Serum superoxide dismutase (SOD) was determined using colorimetric method as described by Martin, et al. [33]. Serum glutathione peroxidase (GPx) was determined using colorimeteric method as described by Paglia and Valentine [34].

\section{Statistical analysis}

The results obtained from the questionnaire were subjected to descriptive statistics. Statistical analysis was performed using computer software programme statistical package for social sciences (SPSS) (version 20.0 SPSS Incorporation, Chicago, IL, USA). The data obtained from protein-energy malnourished children and controls were compared using student's $t$-test. The results obtained from different classes of protein-energy malnourished children and controls were compared using one way analysis of variance (ANOVA). The differences between the various means were compared using Duncan Multiple Range Test. Pearson correlation was used to study the relationship between the trace elements and antioxidant enzymes in both malnourished patients and controls. All results obtained were expressed as mean \pm standard deviation. Values of $p<0.05$ were considered significant.

\section{Results}

\section{Demographic and socio-economic characteristics of study groups}

The number of patients in each class of PEM group is presented in Figure 1. It was observed that $64.29 \%$ out of the 98 patients investigated in the present study, were marasmus. Exactly $26.53 \%$ had kwashiorkor, whereas $9.18 \%$ had both conditions (marasmic-kwashiokor).

Table 1 shows the demographic and socio-economic characteristics of the study groups. The patients and controls subjects had mean age (months) of $18.54 \pm 7.10$ and $18.41 \pm 9.93$ respectively. Majority of the children were in the age group 12-23 months. Most of the PEM patients and controls were Hausas $(89.71 \%)$ and $(70.41 \%)$ respectively. The highest proportions of the PEM patients were from parents with 


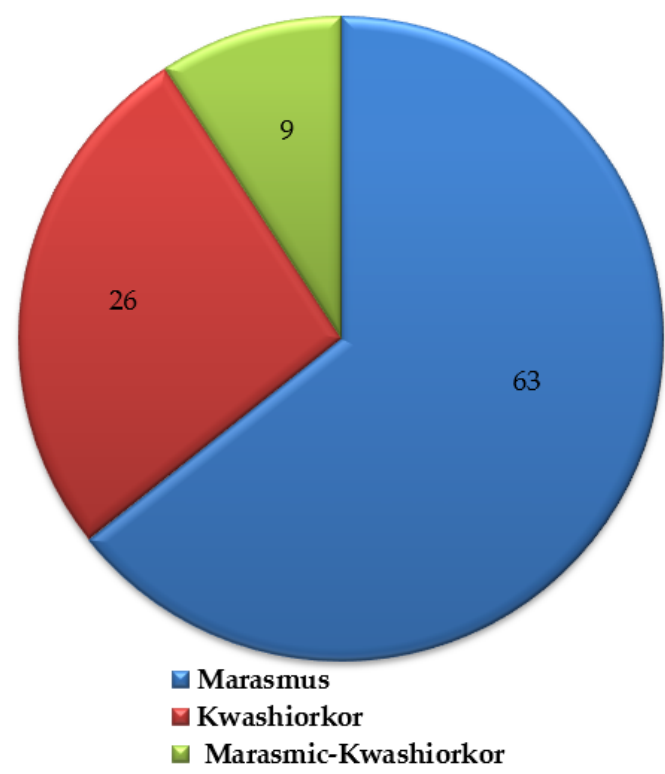

Figure 1. Distribution of Each Class of Protein-Energy Malnutrition among the Study Group.

Table 1. Demographic and socio-economic characteristics of study groups.

\begin{tabular}{|c|c|c|c|c|}
\hline Characteristics & $\begin{array}{c}\text { Number of } \\
\text { PEM Patients }\end{array}$ & Percentage (\%) & $\begin{array}{c}\text { Number } \\
\text { of Control } \\
\text { Subjects }\end{array}$ & Percentage (\%) \\
\hline $\begin{array}{c}\text { Age group } \\
\text { (months) }\end{array}$ & & & & \\
\hline $1-11$ & 14 & 14.29 & 30 & 30.61 \\
\hline $12-23$ & 59 & 60.20 & 35 & 35.71 \\
\hline $24-35$ & 22 & 22.45 & 26 & 26.53 \\
\hline $36-47$ & 2 & 2.04 & 5 & 5.10 \\
\hline $48-59$ & 1 & 1.02 & 2 & 2.04 \\
\hline Sex & & & & \\
\hline Males & 57 & 58.16 & 57 & 58.16 \\
\hline Female & 41 & 41.84 & 41 & 41.84 \\
\hline Ethnicity & & & & 70.41 \\
\hline Hausa & 88 & 89.71 & 69 & 5.10 \\
\hline Yoruba & 0 & 0.00 & 5 & 24.49 \\
\hline Others & 10 & 10.20 & 24 & 27.55 \\
\hline Social class & & & & 39.71 \\
\hline I & 1 & 1.02 & 27 & 16.33 \\
\hline II & 8 & 8.16 & 39 & 8.16 \\
\hline III & 18 & 18.37 & 16 & 8.16 \\
\hline IV & 34 & 34.69 & 8 & 5 \\
\hline V & 37 & 37.76 & 8 & \\
\hline Socias class & 10 & & & \\
\hline
\end{tabular}

Social class: refers to group of people within a society who possesses the same economic and social position based on education, income and occupation. Social classes I and II are people from higher socio-economic status, III and IV are people from lower socioeconomic status. Social class $\mathbf{V}$ are people from the least socio-economic status.

lower economic and educational status (72.45\%), while the controls were from parents with higher economic and educational status (67.26\%).

\section{Feeding characteristics of PEM patients}

Table 2 shows the results of feeding characteristics among PEM patients. The results showed that majority of the patients with PEM and controls were not exclusively breast-fed, (76.53\%) and (63.27\%) respectively. Although, the practice of exclusive breast-feeding was lower in the PEM patients than in the controls. However, less than half of the PEM patients and control subjects were still breast- fed, (38.78\%) and $(44.81 \%)$ respectively.

\section{Serum biochemical parameters of PEM patients}

Table 3, shows the serum biochemical parameters in PEM patients and control subjects. The obtained data indicates that the total protein, albumin, SOD and GPX were significantly lower $(\mathrm{p}<0.05)$ in PEM patients than in the control subjects, while serum zinc concentrations in PEM patients were significantly higher $(\mathrm{p}<0.05)$ than in the control subjects.

\section{Serum total protein and albumin levels in different classes of PEM patients}

Table 4 presents the levels of serum total protein and albumin in different classes of PEM patients. The results show that the serum total protein and albumin levels in marasmus, kwashiorkor and marasmickwashiorkor were significantly lower $(\mathrm{p}<0.05)$ than in controls. However, there was no significant difference $(\mathrm{p}>0.05)$ in serum total protein and albumin levels between kwashiorkor and marasmickwashiorkor, but there was a significant difference $(p<0.05)$ in serum total protein and albumin levels between marasmus with kwashiorkor and marasmic-kwashiorkor.

\section{Serum zinc and copper concentration in different classes of PEM patients}

Table 5 shows the serum zinc and copper concentrations in different classes of PEM patients and control subjects. The serum zinc concentrations in patients with marasmus, kwashiorkor and marasmic-kwashiorkor were significantly higher $(\mathrm{p}<0.05)$ than in control subjects. However, there was no significant difference $(p>0.05)$ in serum copper concentration in marasmus, kwashiorkor and marasmic-kwashiorkor compared with that of the control subjects, but serum copper concentration was significantly higher $(\mathrm{p}<0.05)$ in kwashiorkor compared with that of the marasmic-kwashiorkor.

Serum superoxide dismutase and glutathione peroxidase levels in different classes of PEM patients and control subjects

Serum levels of superoxide dismutase and glutathione peroxidase in different classes PEM patients and control subjects are presented in Table 6. The results show that, superoxide dismutase (SOD) and glutathione peroxidase $(\mathrm{GPx})$ levels were significantly lower $(\mathrm{p}<0.05)$ in marasmus, kwashiorkor and marasmic-kwashiorkor compared with that of the control subjects. However, there was no significant

Table 2. Feeding characteristics of children with PEM and control subjects.

\begin{tabular}{|c|c|c|c|c|}
\hline Characteristics & $\begin{array}{c}\text { Number of } \\
\text { PEM Patients }\end{array}$ & Percentage (\%) & $\begin{array}{c}\text { Number } \\
\text { of Control } \\
\text { Subjects }\end{array}$ & Percentage (\%) \\
\hline $\begin{array}{c}\text { Exclusively } \\
\text { breastfed } \\
\text { children }\end{array}$ & & & & \\
\hline Yes & 23 & 23.47 & 36 & 36.73 \\
\hline No & 75 & 76.53 & 62 & 63.27 \\
\hline Weaning period & & & & \\
\hline$\leq 5$ months & 5 & 5.10 & 1 & 1.02 \\
\hline $6-11$ & 9 & 9.18 & 2 & 2.04 \\
\hline $12-17$ & 20 & 20.41 & 24 & 24.49 \\
\hline$\geq 18$ & 24 & 24.49 & 27 & 27.55 \\
\hline Still breast fed & 38 & 38.78 & 44 & 44.81 \\
\hline Not breast fed & 2 & 2.04 & 0 & 0.00 \\
\hline PEM = Protein-Energy Malnutrition. & & & \\
\hline
\end{tabular}


Njoku SU (2018) Study on the relationship between some trace mineral elements and antioxidant enzymes among under-five children with protein-energy malnutrition

Table 3. Serum biochemical parameters of PEM patients.

\begin{tabular}{|c|c|c|c|c|c|}
\hline Group & Total Protein (gm/dl) & Albumin (gm/dl) & $\begin{array}{c}\text { Zinc } \\
(\mathbf{m g} / \mathbf{l})\end{array}$ & $\begin{array}{c}\text { GPX } \\
\text { (U/l) }\end{array}$ \\
\hline PEM Patients & $55.76 \pm 3.95^{\mathrm{a}}$ & $26.43 \pm 2.78^{\mathrm{a}}$ & $8.37 \pm 4.25^{\mathrm{b}}$ & $2.40 \pm 1.12^{\mathrm{a}}$ & $1.87 \pm 0.32^{\mathrm{a}}$ \\
\hline Control Subjects & $64.72 \pm 2.87^{\mathrm{b}}$ & $37.46 \pm 3.36^{\mathrm{b}}$ & $5.14 \pm 2.39^{\mathrm{a}}$ & $2.82 \pm 1.18^{\mathrm{a}}$ & $2.41 \pm 0.22^{\mathrm{b}}$ \\
\hline
\end{tabular}

Values are Mean \pm SD. Values with different superscripts down the column are significantly different $(\mathrm{p}<0.05)$, Sample size $=98$ per group, $\mathrm{SOD}=\mathrm{Superoxide}$ dismutase, GPx $=$

Glutathione peroxidase, PEM = Protein-Energy Malnutrition.

Table 4. Serum total protein and albumin levels in different classes of PEM patients and control subjects.

\begin{tabular}{|c|c|c|}
\hline Groups & Total Protein $\mathbf{( g m} / \mathbf{d l})$ & Albumin $(\mathbf{g m} / \mathbf{d l})$ \\
\hline Marasmus & $56.57 \pm 3.54^{\mathrm{b}}$ & $26.92 \pm 2.62^{\mathrm{b}}$ \\
\hline Kwashiorkor & $51.20 \pm 2.95^{\mathrm{a}}$ & $23.00 \pm 2.55^{\mathrm{a}}$ \\
\hline Marasmic-kwashiorkor & $51.30 \pm 3.30^{\mathrm{a}}$ & $24.10 \pm 1.73^{\mathrm{a}}$ \\
\hline Control Subjects & $64.72 \pm 2.87^{\mathrm{c}}$ & $37.46 \pm 3.36^{\mathrm{c}}$ \\
\hline
\end{tabular}

Values are means $\pm \mathrm{SD}$. Values with different superscripts are significantly different $(\mathrm{p}<0.05)$ down the column.

Table 5. Serum zinc and copper concentration in different classes of PEM patients and control subjects.

\begin{tabular}{|c|c|c|}
\hline Groups & Zinc (mg/l) & Copper (mg/l) \\
\hline Marasmus & $8.32 \pm 4.32^{\mathrm{b}}$ & $2.73 \pm 0.94^{\mathrm{ab}}$ \\
\hline Kwashiorkor & $9.36 \pm 1.76^{\mathrm{b}}$ & $3.76 \pm 2.49^{\mathrm{b}}$ \\
\hline Marasmic-kwashiorkor & $8.30 \pm 4.77^{\mathrm{b}}$ & $1.96 \pm 1.04^{\mathrm{a}}$ \\
\hline Control Subjects & $5.14 \pm 2.39^{\mathrm{a}}$ & $2.82 \pm 1.18^{\mathrm{ab}}$ \\
\hline
\end{tabular}

Values are means $\pm \mathrm{SD}$. Values with different superscripts are significantly different $(\mathrm{p}<0.05)$ down the column.

Table 6. Serum superoxide dismutase and glutathione peroxidase levels in different classes of PEM patients and control subjects.

\begin{tabular}{|c|c|c|}
\hline Groups & SOD (U/l) & GPx (U/l) \\
\hline Marasmus & $1.92 \pm 0.21^{\mathrm{b}}$ & $43.28 \pm 4.48^{b}$ \\
\hline Kwashiorkor & $1.72 \pm 0.13^{\mathrm{ab}}$ & $35.40 \pm 4.72^{\mathrm{a}}$ \\
\hline Marasmic-kwashiorkor & $1.54 \pm 0.32^{\mathrm{a}}$ & $38.40 \pm 5.25^{\mathrm{a}}$ \\
\hline Control Subjects & $2.14 \pm 0.22^{\mathrm{c}}$ & $58.78 \pm 3.98^{c}$ \\
\hline \multicolumn{3}{|c|}{$\begin{array}{l}\text { Values are means } \pm \text { SD. Values with different superscripts are significantly differen } \\
(\mathrm{p}<0.05) \text { down the column. } \mathrm{SOD}=\text { Superoxide dismutase, GPx }=\text { Glutathione } \\
\text { peroxidase. }\end{array}$} \\
\hline
\end{tabular}

Table 7. Pearson correlation between serum concentrations of zinc and copper with serum levels of SOD and GPX in different classes of PEM patients and control subjects.

\begin{tabular}{|c|c|c|c|}
\hline Groups & & SOD* & GPx $^{*}$ \\
\hline \multirow{2}{*}{ Marasmus } & $\mathrm{Zn}$ & 0.03 & -0.14 \\
\cline { 2 - 4 } & $\mathrm{Cu}$ & 0.16 & 0.05 \\
\hline \multirow{2}{*}{ Kwashiorkor } & $\mathrm{Zn}$ & -0.39 & -0.54 \\
\cline { 2 - 4 } & $\mathrm{Cu}$ & -0.39 & -0.31 \\
\hline \multirow{2}{*}{$\begin{array}{c}\text { Marasmic- } \\
\text { kwashiorkor }\end{array}$} & $\mathrm{Zn}$ & -0.31 & -0.41 \\
\hline \multirow{2}{*}{ Control Subjects } & $\mathrm{Cu}$ & -0.51 & -0.48 \\
\cline { 2 - 4 } & $\mathrm{Zn}$ & 0.12 & -0.07 \\
\hline
\end{tabular}

difference $(p>0.05)$ in the levels of these enzymes in children with kwashiorkor and those with marasmic-kwashiorkor.

\section{Pearson correlation between serum concentrations of zinc and copper with serum levels of SOD and GPX in different classes of PEM patients and control subjects}

Pearson's correlation between serum concentrations of zinc and copper with serum levels of SOD and GPx in different classes of PEM patients and control subjects are presented in Table 7. There were positive correlations between serum zinc and copper with SOD in both marasmus and controls but not in kwashiorkor and marasmickwashiorkor. However, GPx activities were negatively correlated with both zinc and copper in almost all the groups except copper in marasmus.

\section{Discussion}

In this study, the status of both antioxidant enzyme activities together with some relevant trace elements and their possible relationship among under-five children having marasmus, kwashiorkor and marasmic-kwashiorkor as well as apparently healthy children were examined. Majority of the subjects in the present investigation were Hausas. Their lower socioeconomic status as observed, contributed to the inadequate nutritional intake as a result of poverty. Decreased activities of both SOD and GPx in protein-energy malnourished children with marasmus, kwashiorkor and marasmic-kwashiorkor may be due to deficiency of certain trace elements which forms the integral part of these enzymes [35]. Serum $\mathrm{Cu}$ and $\mathrm{Zn}$ are integral parts of $\mathrm{Cu}-\mathrm{Zn}$ SOD containing enzyme $[25,36]$ and Se which is an integral part of Se-GPX containing enzyme [25,37]. It may also be due to harmful levels of free radicals found in children with protein-energy malnutrition (PEM) [21,38]. However, reduction of SOD and GPx activities in kwashiorkor and marasmic-kwashiorkor compared with marasmus, may be related to the severity of the disease. These results are in agreement with the report of El-Hassan, et al. [35] and Golden and Ramadath [38].

Biochemical evidence of serum zinc and copper deficiencies has been reported in children with PEM [27]. Such evidence has also been provided by the present study, with reference to copper but not zinc. Increase in serum zinc levels in children with PEM may be due to environmental zinc contamination, or it could be possible that some of the PEM children were already receiving zinc supplement since PEM is associated with diarrhoea and zinc supplementation has been found to reduce the duration and severity of diarrhoea [39]. In addition, oedema fluid has been found to contain substantial amount of zinc which is protein bound [40]. Although, there was no significant difference in serum zinc levels between marasmus, kwashiorkor and marasmic-kwashiorkor, but there was significant difference between children with PEM and control subjects. Zinc deficiency in apparently healthy children (controls) may be due to, dietary deficiency such as abnormally low zinc content in human milk or the low availability of zinc in cow's milk which is even lower than human milk [40]. Another contributing factor could be low content of zinc in the soil or phytate which is present in most foods of plant origin like whole grain cereals, which constitute the most important sources of nutrients for children in our environment [41] and may also inhibit zinc absorption [42]. These results are in agreement with that of Ashour, et al. [43], who reported elevated zinc levels in children with PEM compared with their control subjects, and also in agreement with Hegazi, [44] who reported low serum zinc level in apparently healthy children in developing countries compared with the children of developed countries. The present work reveals a positive correlation between serum levels of zinc and copper with SOD activity in children with marasmus and control subjects, but shows a negative correlation between serum levels of zinc and copper with SOD activity in children with kwashiorkor and 
Njoku SU (2018) Study on the relationship between some trace mineral elements and antioxidant enzymes among under-five children with protein-energy malnutrition

marasmic-kwashiorkor. However, this study has not demonstrated any positive correlation between serum zinc levels and GPx activity in all the groups.

With respect to serum copper, low level was observed in marasmic children. This may be due to reduction in albumin or ceruloplasmin (copper-carrying protein in the blood) which is attributed to its excessive loss, destruction or inability to be synthesized leading to lack of copper transport to the liver [45]. Another contributing factor that may lead to copper deficiency in marasmic cases is repeated bouts of acute and chronic diarrhoea, as well as malabsorption which are common with PEM children [46]. The results of the present study are in accordance with the reports of Ibrahim [47] and Ashour, et al. [43]. The present study also reveals a positive correlation between serum copper levels and GPx activity in children with marasmus, but shows a negative correlation between serum copper levels and GPx activity in kwashiorkor, marasmic-kwashiorkor and control groups.

The low serum total protein and albumin levels in children with PEM may reflect liver synthetic failure or diseases such as chronic hepatitis among the PEM children. However, decrease levels of total protein and albumin in children with kwashiorkor and marasmic-kwashiorkor compared with marasmus suggests an abnormally low protein in the blood (hypoproteinemia), due to severe limitation of protein intake in the diet. Decreased serum protein decreases the osmotic pressure of the blood, leading to loss of fluid from the intravascular compartment or the blood vessels to the interstitial tissues, resulting in oedema. The present observations in this study are in harmony with those of previous investigators with respect to malnutrition in children $[29,43,48]$.

\section{Conclusion}

Antioxidants play a very important role in the body defense system against reactive oxygen species [25]. The results of this study reveal low levels of SOD and GPx activities in children with PEM which make them liable to certain oxidative effect of reactive oxygen species. The children with PEM are also characterized by low levels of serum copper, total protein and albumin, all pointing to the fact that children with PEM are predisposed to severe oxidative stress. In spite of improvement in food availability and poverty alleviation programmes, Nigeria still stands at a very vulnerable position with one of the highest prevalence of undernutrition in the world like India $[49,50]$. Hence, routine laboratory investigation of blood endogenous antioxidants should be conducted for effective management of PEM. All predisposed under-five children attending the Out-Patient Clinics should be thoroughly examined for signs of malnutrition especially in developing countries like Nigeria. Promotion of good hygienic practice, health education, immunization programmes and family planning, specifically in rural and sub-urban regions in Nigeria should be intensified. Exclusive breast feeding for six months, adequate complementary feeding from six months and food fortification should be encouraged among under-five children in Nigeria as measures against developing PEM.

\section{Conflict of Interest}

The authors declare that there is no conflict of interests regarding the publication of this paper.

\section{Authors' Contribution}

Kola M. Anigo and Shehu A. Akuyam got the concept and design of the study. Stella U. Njoku managed the literature search, carried out the chemical analysis and drafted the very first version of the paper. Gboye O. Ogunrinde participated in the acquisition of data, drafting of the paper, and its subsequent revision. Stanley I. R. Okoduwa carried out the statistical analysis, interpretation of the results and critically revised the drafted manuscript for important intellectual content. All authors gave a final approval of the revised version to be published.

\section{Acknowledgement}

This research work did not receive any specific grant from funding agencies in the public, commercial, or not-for-profit sectors. The authors appreciate parents of the children that participated in this study for their consent. Also to the staff of Out-Patient Clinics at the Department of Paediatrics, Ahmadu Bello University Teaching Hospital (ABUTH), Shika and Banzanzu, Zaria, for their technical assistance during the course of the research.

\section{References}

1. UNICEF (2016) Undernutrition contributes to nearly half of all deaths in children under five and is widespread in Asia and Africa.

2. Suchdev PS (2017) What Pediatricians can do to address malnutrition globally and at home. Pediatrics: e20161666. [Crossref]

3. Valente A, Silva D, Neves E, Almeida F, Cruz JL, et al. (2016) Acute and chronic malnutrition and their predictors in children aged 0-5 years in Sao Tome: a cross sectional, population-based study. Public Health 140: 91-101. [Crossref]

4. Leonor R, Elsa C, Rocio O (2011) Malnutrition and Gastrointestinal and Respiratory infection in children: A public Health Problem. Int $J$ Environ Res Public Health 8: 117-1205. [Crossref]

5. Park SE, Kim S, Ouma C, Loha M, Wierzba TF, et al. (2012) Community management of acute malnutrition in the developing world, Pediatr Gastroenterol Hepatol Nutr 15: 210-219. [Crossref]

6. FAO, IFAD, WFP (2015) The state of food insecurity in the world 2015. Meeting the 2015 International hunger targets: Taking stock of uneven progress. Rome: FAO

7. Whitney E, Rolfes SR (2008) International student edition. In: Thomson W. (Edn). $11^{\text {th }}$ (edn). Understanding Nutrition, Belmont, USA 196-199, 460.

8. Onis MD, Blossner M (1997) WHO global database on child growth and malnutrition. WHO.

9. WHO (World Health Organization) (1993) The worldwide magnitude of protein-energy malnutrition: an overview from the WHO Global Database on Child Growth. Bull. W.H.O 71 : 703-12

10. UNICEF (1990) Strategies of Improving Nutrition of Children and Women in Developing Countries: United Nations Children's Fund. New York.

11. UNICEF (2013) The state of the world's children. Adolescence: Children with disabilities.

12. Abubakar N, Atiku MK, Alhassan AJ, Mohammed IY, Garba RM, (2017) An assessment of micronutrient deficiency: A comparative study of children with proteinenergy malnutrition and apparently healthy controls in Kano, Northern Nigeria. Trop $J$ Med Res 20: 61-65.

13. Scrimshaw NS, Viteri FE (2010) Studies of kwashiorkor and marasmus. Food Nutr Bull 31: 34-41. [Crossref]

14. Jahoor F, Badaloo A, Reid M, Forrester T (2008) Protein metabolism in severe childhood malnutrition. Ann Trop Paediatr 28: 87-101. [Crossref]

15. Wellcome Trust Working Party (1970) Classification of infantile malnutrition. Lancet 2: 302-303. [Crossref]

16. Brabin BJ, Coulter JBS (2003) Nutrition associated disease. In: Cook GC, Zumla AI, editors. Manson's tropical diseases. Saunders, London, England: 561-80.

17. Ubesie AC, Ibeziako NS, Ndiokwelu CI, Uzoka CM, Nwafor CA (2012) Under-five protein energy malnutrition admitted at the University of Nigeria Teaching Hospital, Enugu: A 10 year retrospective review. Nutrition Journal 11: 43.

18. Nigeria Demographic and Health survey (2008) Summary of child Nutritional Status.

19. Alegbejo JO, Yakubu AM (1993) Protein-energy malnutrition: a ten year retrospective study (1980-1990). Nig Med Pract 25: 29-32

20. Robinson MK, Rustum RR, Chambers EA, Rounds JD, Wilmore DW, et al. (1996) Starvation enhances hepatic free radicals release. J Surg Res 69 (2): 325-330. [Crossref 
Njoku SU (2018) Study on the relationship between some trace mineral elements and antioxidant enzymes among under-five children with protein-energy malnutrition

21. Golden MH, Ramadath D, Golden BE (1990) Free radical and malnutrition. In: Dreosti I and Clinfton NJ (Eds). Trace elements, micronutrients and free radicals pp. 87-89.

22. Okoduwa SIR, Umar IA, Ibrahim S, Bello F, Habila N (2015) Age dependent alteration of antioxidant defense system in hypertensive and type-2 diabetes patients. $J$ Diabetes Metab Disord 14: 32. [Crossref]

23. Deavall DG, Martin EA, Horner JM, Roberts R (2012) Drug-Induce oxidative stress and toxicity. $J$ Toxicol 10: 1155-1168.

24. Gil L, Siems W, Mazurek B, Gross J, Schroeder P, et al. (2006) Age associated analysis of oxidative stress parameters in human plasma and erythrocytes. Free Radic Res 40 : 405-505. [Crossref

25. Okoduwa SIR, Umar IA, Sani I, Bello F (2013) Relationship of oxidative stress with type-2 diabetes and hypertension. J Diabetol 1: 2 .

26. Stahl W, Sies H (1997) Antioxidant defense: Vitamins E, C and carotenoids. Diabetes 46: 14-18. [Crossref]

27. Sive AA, Subotzky BF, Halon H, Dempster WS, Heese HD (1993) Red blood cell antioxidant enzyme concentration in PEM. Ann Trop Pediatr 13: 33-38. [Crossref]

28. Houssaini FZ, Iraqi MR, Arnaoud J, Chard MJ (1997) Trace elements and proteincalorie malnutrition in the Fes area (Morocco). Biomed Pharmacother 51: 349-351. [Crossref]

29. Ugwuja EI, Nwosu KO, Ugwu NC, Okonji M (2007) Serum Zinc and Copper Levels in Malnourished Pre-school Age Children. Pak J Nutr 6: 349-354.

30. Olusanya O, Okpere E, Ezimokhai M, Olusanya O, Okpere O (1985) The importance of socio-economic class in voluntary fertility control in a developing country. WAJM 4: $205-262$

31. Reinhold JG (1953) Total protein, albumin and globulin. In: Standard methods in clinical chemistry. M. Reiner (Edn). Academic Press, New York, 88.

32. Hill PG (1985) The measurement of albumin in serum and plasma. Ann Clin Biochem 22: 565-578. [Crossref]

33. Martin JP Jr, Dailey M, Sugarman E (1987) Negative and Positive Assays of Superoxide Dismutase Based on Hematoxylin Autoxidation. Arch Biochem Biophys 255: 329-336. [Crossref]

34. Paglia DE, Valentine WN (1967) Studies on the quantitative and qualitative characterization of erythrocyte glutathione peroxidase. J Lab Clin Med 70: 158-169. [Crossref]

35. El-Hassan SMA, Abdelrazik NM, Abd El-Aziz AEF, El-Iraqi RR (2004) Assessment of the relation between trace elements and antioxidant status in children with protein energy malnutrition. The Int $J$ Pediatr and Neonatol $4: 1$.
36. Vallee BL, Auld S (1990) Zinc coordination, function and structure of zinc enzymes and other proteins. Biochem.; 29: 564-577.

37. Levander OA, Burk RF (1990) Selenium. In: Present Knowledge in Nutrition. $6^{\text {th }}$ (edn) M.L. Brown, E.D. Nutrition Foundation, Washington, D.C., U.S.A: 268-273.

38. Golden MH, Ramadath D (1987) Free radicals in the pathogenesis of kwashiorkor and marasmus. Proc Nut Soci 46: 53-68. [Crossref]

39. Bhutta ZA, Nizami SQ, Isani Z (1999) Zinc supplementation in malnourished children with persistent diarrhoea in Pakistan. Pediatrics 103: 1-9. [Crossref]

40. Kumar S, Rao KSJ (1973) Plasma and erythrocyte zinc levels in protein-energy malnutrition. Nutr Metabol 15: 364 -371. [Crossref]

41. Casey CE, Walravens PA, Hambidge KM (1981) Availability of zinc: Loading test with human milk, cow?s milk and infant formulas. Pediatrics 68: 324-326. [Crossref]

42. Dijkhuizen MA, Wieringa FT, West CE, Muhilal A (2004) Zinc plus $\beta$-carotene supplementation of pregnant women is superior to $\beta$-carotene supplementation alone in improving vitamin A status in both mothers and infants. Am J Clin Nutr 80: 12991307. [Crossref]

43. Ashour MN, Salem SI, El-Gadban HM, Elwan NM, Basu TK (1999) Antioxidant status in children with protein-energy malnutrition. Eur J Clin Nutr 53: 669-673. [Crossref]

44. Hegazi MA (2002) Study of some trace elements in relation to growth in infancy and early childhood. M.D degree of Pediatrics. Mansoura University, Egypt.

45. Hansen IDL, Lehman BH (1969) Serum zinc and copper concentrations in children with protein calorie malnutrition. S Afr Med J 43: 1248-1251.

46. Mehta HC, Saini AS, Singh H, Dhatt PS (1984) Biochemical aspects of malabsorption in marasmus. Br J Nutr 51: 1-6. [Crossref]

47. Ibrahim MA (1990) Evaluation of some trace elements in P.E.M., M.Sc degree of Ped. Zagazig University, Egypt.

48. Yameogo CW, Cichon B, Fabiensen C, Luel-Brockdorf A, Shepherd S, et al. (2017) Correlates of physical activity among young children with moderate acute malnutrition. The J Pediatr 181: 235-241. [Crossref]

49. Bhutia DT (2014) Protein energy malnutrition in India: The plight of our under five children. J Fam Med Primary Care 4: 63-67. [Crossref]

50. Abera L, Dejene T, Laelago T (2017) Prevalence of malnutrition and associated factors in children aged 6-59 months among rural dwellers of demot gale district, south Ethiopia: community based cross sectional study. Int J Equity Health 16: 111

Copyright: (C2018 Njoku SU. This is an open-access article distributed under the terms of the Creative Commons Attribution License, which permits unrestricted use, distribution, and reproduction in any medium, provided the original author and source are credited. 